\section{9 Countries act to prevent
shortages of rare earths}

A $\mathrm{s}$ demand for rare earths and other raw materials rises, countries around the world are engaging in strategic planning, negotiating international partnerships, and exploring new sources of rare earths. Although the countries have varied goals and policies, the underlying aim is the same for each - ensuring reliable access to the raw materials that sustain ongoing research, development, and manufacturing.

China produced over $97 \%$ of the 124,000 metric tons of rare earths produced in 2009, but this model is not sustainable. The demand for rare earths and other raw materials is rising around the world, as is the demand for these materials within China. Export levels from China are dropping dramatically and this trend is likely to continue. China may be a net importer of rare earths as soon as 2015, according to a statement read at the Critical Metals Investment Symposium in January 2011 on behalf of Zhanheng Chen, Academic Director of the Chinese Society for Rare Earths.

In the last few years, several countries have created strategic plans to avoid disruptions in their raw materials supply chain. For example, the European Commission published the Raw Materials Initiative in November 2008 and adopted an updated strategy document in February 2011. The United States Department of Energy released Critical Materials Strategy in December 2010 (for details on the strategy, see SCIEnCE Policy in the March 2011 issue of MRS Bulletin, p. 158). South Korea's Ministry of Knowledge Economy released Plans for Stable Procurement of Rare Metals in October 2010. The Ministry of Economy, Trade and Industry in Japan released Strategy for Ensuring
Stable Supplies of Rare Materials in July 2009.

The policies taking shape around the world address the stability of the raw materials supply from many angles: recycling end-use products, researching and developing potential rare earth substitutes, supporting new mining efforts, building strategic partnerships with other nations, and stockpiling resources while they are still available. Many countries have strategies that incorporate several or all of these methods.

The European Union's (EU) strategy for ensuring access to raw materials has three components: better exploit resources in the EU, find new rare earth sources abroad, and boost the recycling of rare earths. Recycling rare earths is costly and difficult, and until recently has not been seen as economically viable. However, many countries are now revisiting this issue. In particular, the EU is looking at ways to spur recycling innovation and develop best practices in the collection and treatment of waste, in addition to cutting down on the illegal shipments of electronics scrap to developing countries.

Rare earths are essential to Japan's automotive and electronics industries. A key aspect of its strategy is researching materials that could replace those with limited supplies. For example, projects are underway to replace the indium in transparent electrodes with zinc and create magnets without dysprosium. In 2012, Toyota is planning to debut a battery-powered RAV4 with a hybrid induction motor that does not use any rare earth elements.

After short-term disruptions in rare earth exports from China in 2010, Japan will likely accelerate resource-related di- plomacy, said Tetsuro Urabe, who led a study informing Japan's Strategy for Ensuring Stable Supplies of Rare Metals. And it is likely to convince the Japanese government to delay impending cuts to basic science funding, he said.

Efforts are underway in many countries to start or restart rare earth mining operations. Historically, India, Brazil, South Africa, and the United States have been major rare earth suppliers, but the majority of mines outside of China closed in the 1990s when they could no longer compete. Restarting mining operations is time-consuming and expensive, but is becoming an attractive option for many countries.

Mountain Pass, a once profitable mine in California that shut down almost 10 years ago, is expected to produce up to 40,000 metric tons of rare earth oxides a year after reopening in 2012. The new owner, Molycorp Minerals, was initially planning to produce about half of this amount, but in January 2011 announced plans to double production. In a letter to its Web site visitors, CEO Mark Smith writes, "While in recent years China has managed to supply the entire world's demand for Rare Earths, a dramatic shift is beginning to take place....With appropriate federal assistance for research, development and capital costs, Molycorp Minerals is prepared to move forward to reestablish domestic manufacturing capacity on an expedited basis."

Like many other countries, Germany is looking to secure its raw materials supply through new international partnerships. Kazakhstan is one potential partner, with an attractive supply of raw materials. The two countries have been in talks about an exclusive deal for months. This would require a large investment because Kazakhstan does not currently have the infrastructure to support a high level of mining operations. Japan and South Korea are also looking to this region for supplies, as well as to Africa, Australia, and Vietnam, among other places.

In addition to these efforts, many countries are stockpiling critical materials or considering the option. Newly built storage facilities in China are esti- 
Policy Goals, Business Policies, Research and Development Policies, and Materials of Interest for Each Nation

\begin{tabular}{|c|c|c|c|c|}
\hline Nation & Goal & Business Policy & R\&D Policy & $\begin{array}{l}\text { Materials } \\
\text { of Interest }\end{array}$ \\
\hline Japan & $\begin{array}{l}\text { Secure a stable supply of } \\
\text { raw materials for Japanese } \\
\text { industries }\end{array}$ & $\begin{array}{l}\text { - Funding for international } \\
\text { mineral exploration } \\
\text { - Loan guarantees for high-risk } \\
\text { mineral projects } \\
\text { - Stockpiling } \\
\text { - Information gathering }\end{array}$ & $\begin{array}{l}\text { - Substitution research funded } \\
\text { through METI and MEXT } \\
\text { - Exploration, excavation, } \\
\text { refining and safety research } \\
\text { funded through JOGMEC }\end{array}$ & $\begin{array}{l}\mathrm{Ni}, \mathrm{Mn}, \mathrm{Co}, \mathrm{W} \\
\mathrm{Mo}, \mathrm{V}^{* *}\end{array}$ \\
\hline European Union & $\begin{array}{l}\text { Limit the impact of potential } \\
\text { material supply shortages on } \\
\text { the European economy }\end{array}$ & $\begin{array}{l}\text { - Mineral trade policy for open } \\
\text { international markets* } \\
\text { - Information gathering* } \\
\text { - Land permit streamlining* } \\
\text { - Increased recycling regulations* }\end{array}$ & $\begin{array}{l}\text { - Increased material efficiency } \\
\text { in applications } \\
\text { - Identification of material } \\
\text { substitutes } \\
\text { - Improve end-of-life product } \\
\text { collection and recycling } \\
\text { processes }\end{array}$ & $\begin{array}{l}\mathrm{Sb}, \mathrm{Be}, \mathrm{Co}, \mathrm{Ga} \text {, } \\
\mathrm{Ge}, \mathrm{In}, \mathrm{Mg}, \mathrm{Nb}, \\
\text { REEs, Ta, W, } \\
\text { Fluorspar and } \\
\text { Graphite }\end{array}$ \\
\hline Netherlands & $\begin{array}{l}\text { Reduce material } \\
\text { consumption to prevent } \\
\text { global shortages by } \\
\text { employing "managed austerity" }\end{array}$ & $\begin{array}{l}\text { - Government-industry } \\
\text { collaboration on material policy } \\
\text { through the M2i Institute }\end{array}$ & $\begin{array}{l}\text { - Substitutes of abundant or } \\
\text { renewable materials } \\
\text { - Processes for recycling } \\
\text { depleting materials } \\
\text { - Study consumption patterns } \\
\text { as a result of policy }\end{array}$ & $\begin{array}{l}\mathrm{Ag}, \mathrm{As}, \mathrm{Au}, \mathrm{Be}, \\
\mathrm{Bi}, \mathrm{Cd}, \mathrm{Co}, \mathrm{Ga}, \\
\mathrm{Ge}, \mathrm{Hg}, \mathrm{In}, \mathrm{Li} \\
\mathrm{Mo}, \mathrm{Nb}, \mathrm{Nd}, \mathrm{Ni}, \\
\mathrm{Pb}, \mathrm{Pd}, \mathrm{PGMs} \\
\mathrm{REEs}, \mathrm{Re}, \mathrm{Ru}, \\
\mathrm{Sb}, \mathrm{Sc}, \mathrm{Se}, \mathrm{Sn}, \\
\mathrm{Sr}, \mathrm{Ta}, \mathrm{Te}, \mathrm{Ti}, \mathrm{V} \\
\text { W, Y, Zn, Zr }\end{array}$ \\
\hline China & $\begin{array}{l}\text { Maintain a stable supply of } \\
\text { raw materials for } \\
\text { domestic use through industry } \\
\text { consolidation, mitigating } \\
\text { overproduction and reducing } \\
\text { illegal trade }\end{array}$ & $\begin{array}{l}\text { - Taxes and quotas on REE exports } \\
\text { - Prohibition of foreign companies } \\
\text { in REE mining } \\
\text { - Industry consolidation } \\
\text { - Unified pricing mechanisms* } \\
\text { - Production quotas } \\
\text { - Moratorium on new mining per- } \\
\text { mits until mid-2011 }\end{array}$ & $\begin{array}{l}\text { - Rare earth separation } \\
\text { techniques and exploration } \\
\text { of new rare earth functional } \\
\text { materials } \\
\text { - Rare earth metallurgy; optical, } \\
\text { electrical, and magnetic } \\
\text { properties of rare earths; basic } \\
\text { chemical sciences of rare earths }\end{array}$ & $\begin{array}{l}\mathrm{Sb}, \mathrm{Sn}, \mathrm{W}, \mathrm{Fe}, \\
\mathrm{Hg}, \mathrm{Al}, \mathrm{Zn}, \mathrm{V}, \mathrm{Mo} \text {, } \\
\text { REEs }\end{array}$ \\
\hline South Korea & $\begin{array}{l}\text { Ensure a reliable supply of } \\
\text { materials critical to Korean } \\
\text { mainstay industries }\end{array}$ & $\begin{array}{l}\text { - Financial support for Korean firms } \\
\text { at overseas mines } \\
\text { - Free Trade Agreements and } \\
\text { MOUs with resource-rich nations } \\
\text { - Stockpiling }\end{array}$ & $\begin{array}{l}\text { - Recycling end-use products } \\
\text { - Designing for recyclability } \\
\text { - Substitute materials } \\
\text { - Production efficiency }\end{array}$ & $\begin{array}{l}\text { As, Ti, Co, In, } \\
\text { Mo, Mn, Ta, Ga, } \\
\text { V, W, Li and } \\
\text { REEs }\end{array}$ \\
\hline Australia & $\begin{array}{l}\text { Maintain investment in } \\
\text { the mining industry while } \\
\text { fairly taxing the depletion of } \\
\text { national resources }\end{array}$ & $\begin{array}{l}\text { - Low tax on the value of extracted } \\
\text { resources } \\
\text { - High tax on mine profits } \\
\text { - Tax rebates for mineral exploration } \\
\text { - Fast turnaround for land permit } \\
\text { applications }\end{array}$ & $\begin{array}{l}\text { - Promote sustainable } \\
\text { development practices in } \\
\text { mining }\end{array}$ & $\begin{array}{l}\text { Ta, No, V, Li and } \\
\text { REEs }\end{array}$ \\
\hline Canada & $\begin{array}{l}\text { Promote sustainable } \\
\text { development and use of } \\
\text { mineral and metal resources, } \\
\text { protect the environment and } \\
\text { public health and ensure an } \\
\text { attractive investment climate }\end{array}$ & $\begin{array}{l}\text { - Promote a recycling industry and } \\
\text { incorporate recycling as part of } \\
\text { product design } \\
\text { - Require accountability in } \\
\text { environmental performance and } \\
\text { mineral stewardship } \\
\text { - Use life-cycle-based approach to } \\
\text { mineral management and use }\end{array}$ & $\begin{array}{l}\text { - Provide comprehensive } \\
\text { geosciences information } \\
\text { infrastructure } \\
\text { - Promote technological } \\
\text { innovation in mining processes } \\
\text { - Develop value-added mineral } \\
\text { and metal products }\end{array}$ & $\begin{array}{l}\mathrm{Al}, \mathrm{Ag}, \mathrm{Au}, \mathrm{Fe}, \mathrm{Ni} \text {, } \\
\mathrm{Cu}, \mathrm{Pb}, \mathrm{Mo}\end{array}$ \\
\hline *proposed policy & nt reserves & \multicolumn{3}{|c|}{ Source: U.S. Department of Energy, Critical Materials Strategy (2010) p. 61.} \\
\hline
\end{tabular}

mated to hold nearly 40,000 metric tons. Japan and South Korea have both started to stockpile some rare earths, and discussions are underway in the EU and the
United States. However, a recent report by the American Physical Society and Materials Research Society cautions that stockpiling resources can stifle innova- tion (for details on this report, see www. mrs.org/advocacy/ece).

Kendra Redmond 


\section{in situ NanoProcesses}
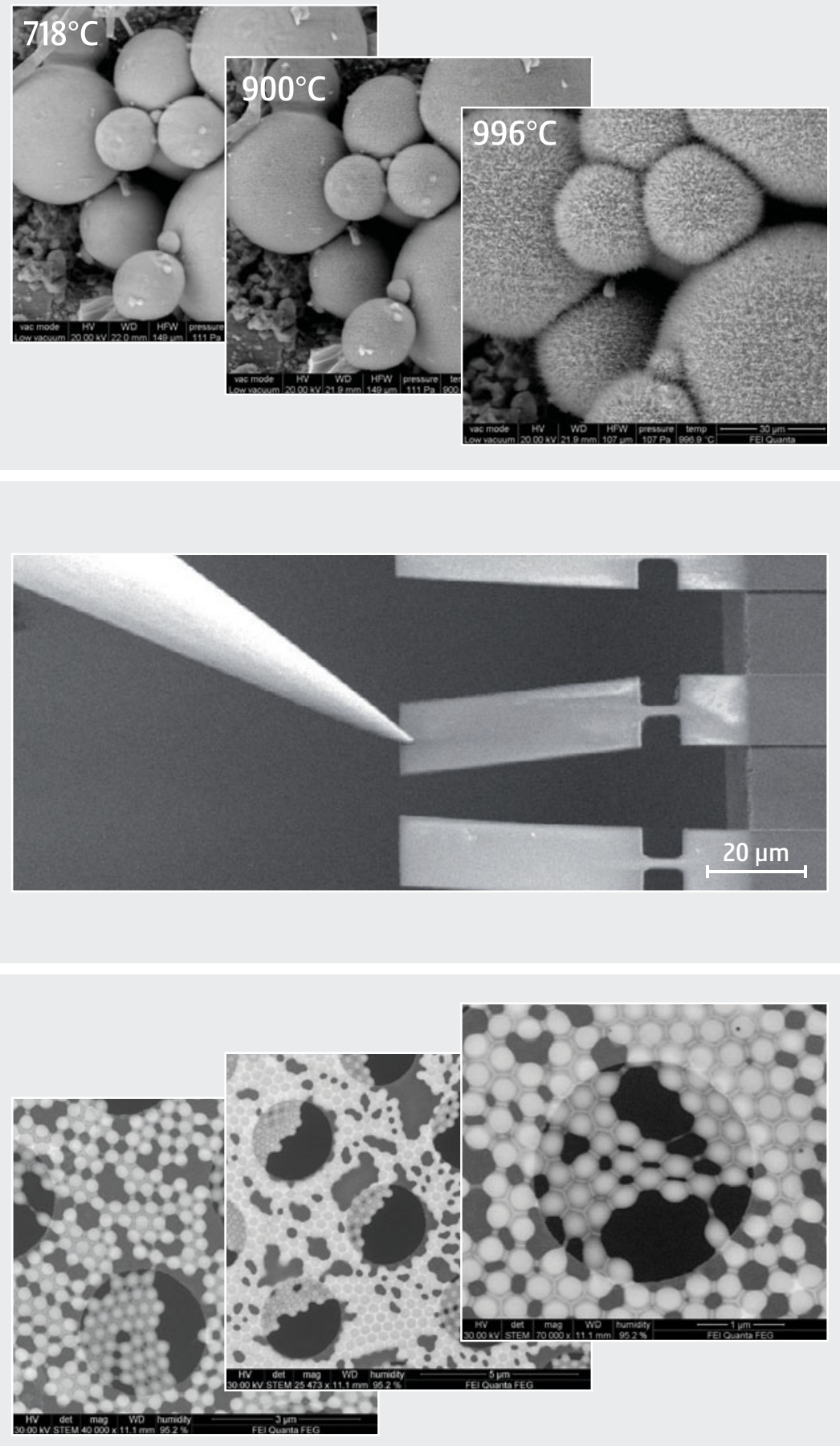

Courtesy of the

Cavendish Laboratory, Cambridge University, United Kingdom

\section{Heating effects}

in situ heating of metal spheres allows monitoring of surface morphology development

\section{Mechanical testing}

in situ probing of a nanocantilever at cryogenic temperatures gives valuable insight into mechanical properties

\section{Wet samples}

in situ wetSTEM observation of latex spheres shows formation of crystallographic clusters 